\title{
Moral Disengagement Level of Team Athletes Depending on Unethical Behaviors They Perceived from Their Coaches
}

\author{
Burcu Guvendi ${ }^{1} \&$ Ayse Turksoy Isim $^{1}$ \\ ${ }^{1}$ Faculty of Sport Sciences, Istanbul University-Cerrahpasa, Turkey \\ Correspondence: Burcu Guvendi, Faculty of Sport Sciences, Istanbul University-Cerrahpasa, Turkey. E-mail: \\ burcu.guvendi@istanbul.edu.tr
}

Received: May 13, 2019

Accepted: June 8, 2019 Online Published: July 4, 2019

doi:10.5539/jel.v8n4p83

URL: https://doi.org/10.5539/jel.v8n4p83

\begin{abstract}
The aim of this study is to determine the correlation between moral disengagement level of team athletes and unethical behaviors they perceived from their coaches by examining moral disengagement level of team athletes depending on unethical behaviors they perceived from their coaches. The target population of the study consists of 305 team athletes whose age average is $20.45 \pm 4.68$ and who are training with the same trainer for average of $2.01 \pm 1.69$ years and from basketball, football and volleyball branches. In this study, "Moral Disengagement in Sport" and "Athlete's Perception about Coaches' Unethical Behaviors" scales have been used as data collection tools. Descriptive statistics, $t$ test, ANOVA and Pearson Correlation analysis were used for the analysis of data. According to the findings of the study, it was observed that there was a positive low level of correlation between moral disengagement and athlete's perception about unethical behaviors of the coach. Younger athletes have a higher perception about unethical behavior they perceived from coaches. Moral disengagement scores of male athletes, athletes who did not take part in national team and athletes who were punished were significantly higher. Significant difference was observed in moral disengagement and in the sub-dimensions of the athletes' perception about their coaches' unethical behavior scales by branch. When the meeting level of athletes with their coaches in the social environment examined, it was seen that there was a significant difference in all sub-dimensions of the athlete's perception regarding the coach's unethical behaviors scale. When athlete's level of communication with their coaches was examined, there was a significant difference in all sub-dimensions of the athlete's perception regarding the coach's unethical behaviors scale. As a result, as the level of unethical behavior that athletes perceived from their coaches increases, the level of moral disengagement also increases.
\end{abstract}

Keywords: moral, ethic, sport, coach

\section{Introduction}

The moral development, which is defined as the system of values that exists in the developmental process of the individual, is formed on the basis of thoughts and beliefs about what are the values such as right-wrong, good-bad etc. (Topkaya, 2007). According to İnanç et al. (2004), psychological researches reveal three dimensions of moral development which are cognitive, behavioral, and emotional dimensions. In the cognitive dimension, the attitudes related to the ethical rules, the relationship with the real behaviors that require the consideration of ethical principles in the behavioral dimension, and in the emotional dimension, the feelings such as guilt, sharing, empathy and cooperation are focused on.

The basis of sport is competition and the aim is to win. But the spirit of Fair Play is required to win morally (Eitzen, 2006). It is the basic principle of sports ethics that athletes adopt universal moral values and apply them in their actions in sporting events (Charles, 1999).

These moral values include general principles such as respect for the opponent, honesty, justice, tolerance, solidarity, not benefiting from undeserved gain, not to discriminate people by their religion, language and race, not deceiving the rival, the arbitrator and even the people (Tanriverdi, 2012). In sports, the most necessary place where gentlemanliness is required, are competitions or match sports. From the amateurship towards professionalism, the need for sportive virtue increases because the expectation in professionalism is to succeed. Sport is an activity that the individual will compete with all the power in accordance with the rules and will respect and value his opponent. If not, there are only fight and hostility instead of sport. For an athlete asking his/her opponent if $\mathrm{s} / \mathrm{he}$ is good after s/he accidentally tackles his/her opponents to the ground, for a coach to 
warn his players not to make movements for stealing time, for athletes to correct wrong whistles and behave by considering the safety and health of the opponent and strictly obeying the rules can be considered as examples of sporting behaviors (Elik, 2017). Individuals belonging to a profession group are expected to display behaviors that show that they are fair and value human beings when fulfilling their requirements. Qualification in a profession is related not only to have knowledge and skills related to that field, but also to have the right attitudes and behaviors related to the field (Dolaşır-Tuncel \& Büyüköztürk, 2009). This is also applicable for coaches who are one of the indispensable elements of the sporting environment. The trainer's duty is not just to train the athletes or to show how the sporting skills are done. A coach should transfer the information that they received from sports scientists, sports physicians and sports psychologists to athletes after interpreting and comparing the information with his/her own knowledge (Baser, 1998). In addition, coaches should understand how the athlete feels in training environment, during and after competition or in cases of success or failing and should put himself in the athlete's shoes (Karakoç et al., 2011). But, most importantly, if it is considered that the compulsory behavior of the coach is an important factor for the goodness of the team climate, in a sense, whether athletes show better performance or not depends on the behaviors of the coach (Tiryaki, 2000). The behaviors of coaches must be in accordance with the universally accepted and adopted values. In other words, like other occupational groups, the profession of coaching is expected to have professional ethical principles on the basis of universal values (Dolaş-Tuncel \& Büyüköztürk, 2009). The coach-athlete relationship is a concept used to describe the fact that the athletes and their coaches are mutually influenced by each other's feelings, thoughts, and behaviors (Avc1 et al., 2018).

It can be said that a healthy coach-athlete relationship process is one of the important criteria for achieving success in sports. Since sport has become an instrument for some purposes rather than its real purpose and the moral values have gradually replaced by material values, for athletes, and the coaches not obeying some ethical principles in their behaviors while performing their duties lead to adverse events in the name of sports. When the literature was reviewed, no studies have been found about the team athletes' moral disengagement levels depending on the unethical behaviors that they perceived from their coaches, while it is seen that many studies have been conducted within the scope of ethical issues in physical education and the sports. From this point of view, the aim of this research is to examine the moral disengagement levels of the team athletes depending on the unethical behaviors they perceived from their coaches.

\section{Method}

\subsection{Study Model}

The study used the screening model. The screening model is an approach to research which aims for describing a condition which occurred in the past or occurs in the present as it is (Büyüköztürk, 2012).

\subsection{Study Group}

The study group of this research consists of a total of 305 team athletes including 152 female and 153 males, whose age average is $20.45 \pm 4.68$ and who train with the same coach for average of $2.01 \pm 1.69$ years, from the basketball, football and volleyball branches.

\subsection{Data Collection Tools}

In this study, moral disengagement in sport scale and athlete's perception regarding coaches' unethical behaviors scale were used as data collection tools.

Athlete's Perception Regarding Coaches' Unethical Behaviors Scale: The scale developed by Güven and Öncü (2012) consists of 19 items and 3 factors. Since all of the items in the 1st factor are related to the coach-athlete relationship, this factor was named as the coach-athlete relationship dimension. Since the items in the 2nd factor are related to the sportsmanship understanding of the coaches, the factor was named as 'sportsmanship dimension' and 3rd factor was named as 'personality traits dimension' because the items in this factor are related to the personal traits of the coaches. The scale is 5-point Likert scale. Expression options; Strongly Agree, Agree, Neither agree or disagree, Disagree, Strongly Disagree; that were scored respectively as " $5,4,3,2$ and 1". In order to test the reliability level of the scale, Cronbach Alpha reliability coefficient and split-half reliability test coefficients were examined. These values were calculated as 0.93 and 0.83 , respectively.

Moral Disengagement in Sports Scale: Moral Disengagement in Sport Scale-Short (MDSSS) developed by Boardley and Kavussanu (2008), was adapted to Turkish by Gürpınar (2015). It is 7-point Likert-type scale that is scored as Strongly disagree (1), Disagree (2), Somewhat Disagree (3), Neither agree or disagree (4), Somewhat Agree (5), Agree (6) and Strongly Agree (7). The scale has 8 items and one factor. All the items for measuring moral disengagement attitudes in sport have negative meaning. Higher scores obtained from the scale 
mean that athletes have much moral disengagement (Gürpınar, 2015). The calculated alpha coefficient to determine the reliability of the scale was found as 0.78 .

\subsection{Data Analysis}

In the analysis of the data obtained from the research, SPSS 20 package program was used. First, the Kolmogorov-Smirnov test was applied to determine whether the data showed normal distribution. When the $p$ values obtained from the Kolmogorov-Smirnov test were analyzed, it was noted that the distribution of the scores was suitable for the normal distribution $(p>0.05)$. Descriptive statistics (frequency, arithmetic mean, standard deviation) as a statistical method for evaluating data; T-test was used for comparison of the scores of the participants' in terms of gender, invitation to national team, whether or not they are penalized, the level of interviewing with their trainers, and the variables in which interviewing in social settings affects team cohesion is included. One way variance analysis (ANOVA) was used according to the evaluation of variables in terms of age, branch, and their communication with trainers. In order to determine the significant difference among groups as a result of ANOVA analysis, Tukey multiple comparison tests were applied. Also, Pearson correlation tests were used to determine whether there is a correlation between the two scales.

\section{Results}

The findings of the study, which was conducted in order to examine the unethical behavior perceived by team athletes from coaches based on team athletes' moral disengagement levels, were as follows:

Table 1. Average scores of scales

\begin{tabular}{lllll}
\hline & $\mathrm{N}$ & Min. & Max. & Mean \pm Std. Dev. \\
\hline Moral Disengagement & 305 & 1.00 & 7.00 & $3.02 \pm .989$ \\
Coach-Athlete Relationship Dimension & 305 & 1.00 & 5.00 & $2.44 \pm 1.022$ \\
Coach's Sportsmanship Dimension & 305 & 1.00 & 5.00 & $1.68 \pm .732$ \\
Coach's Personality Traits Dimension & 305 & 1.00 & 5.00 & $2.26 \pm 1.180$ \\
\hline
\end{tabular}

When we look at the mean values of the scales in Table 1, it was seen that the athletes slightly disagree with moral disengagement, disagree with coach-athlete relationship and personality traits dimensions in the scale of the athlete's perception regarding the coach's unethical behaviors, and they strongly disagree with the unethical behaviors in the sporting dimension.

Table 2. Anova analysis results of moral disengagement and athlete's perception regarding the coaches' unethical behaviors scales by age

\begin{tabular}{|c|c|c|c|c|c|c|}
\hline & Age & $\mathrm{n}$ & Mean \pm Std. Dev. & $\mathrm{F}$ & $\mathrm{p}$ & Tukey \\
\hline Moral & $16-18$ & 133 & $3.05 \pm .997$ & 1.742 & .177 & \\
\hline \multirow[t]{2}{*}{ Disengagement } & $19-21$ & 82 & $3.09 \pm 1.00$ & & & \\
\hline & 23 and over & 77 & $2.82 \pm .925$ & & & \\
\hline \multirow[t]{3}{*}{ Coach-Athlete Relationship } & $16-18$ & 133 & $2.16 \pm 1.058$ & 9.089 & .000 & $16-18 / 19-21$ \\
\hline & $19-21$ & 82 & $2.70 \pm 1.084$ & & & $16-18 / 23$ and over (age) \\
\hline & 23 and over & 77 & $2.62 \pm 1.024$ & & & \\
\hline Coach's Sportsmanship & $16-18$ & 133 & $1.50 \pm .558$ & 8.048 & .000 & $16-18 / 19-21$ \\
\hline \multirow[t]{2}{*}{ Dimension } & $19-21$ & 82 & $1.83 \pm .851$ & & & 16-18/23 and over (age) \\
\hline & 23 and over & 77 & $1.86 \pm .816$ & & & \\
\hline Coach's Personality Traits & $16-18$ & 133 & $1.95 \pm .961$ & 9.434 & .000 & $16-18 / 19-21$ \\
\hline \multirow[t]{2}{*}{ Dimension } & $19-21$ & 82 & $2.57 \pm 1.337$ & & & $16-18 / 23$ and over \\
\hline & 23 and over & 77 & $2.51 \pm 1.186$ & & & \\
\hline
\end{tabular}

In Table 2, while there was a significant difference $(p<0.05)$ in all sub-dimensions of athlete's perception regarding the coach's unethical behaviors scale by age, no significant difference was observed $(p>0.05)$ in moral disengagement scale. 
Table 3. T-test analysis results of moral disengagement and athlete's perception regarding the coaches' unethical behaviors scales by gender

\begin{tabular}{llllll}
\hline & Gender & $\mathrm{n}$ & Mean Std.Dev. & $\mathrm{t}$ & $\mathrm{p}$ \\
\hline Moral disengagement & Female & 152 & $2.78 \pm .930$ & -4.276 & .000 \\
& Male & 153 & $3.26 \pm .992$ & & \\
Coach-Athlete Relationship & Female & 152 & $2.49 \pm 1.02$ & .854 & .394 \\
& Male & 153 & $2.39 \pm 1.02$ & & \\
Coach's Sportsmanship Dimension & Female & 152 & $1.66 \pm .735$ & -.508 & .612 \\
& Male & 153 & $1.71 \pm .731$ & & \\
Coach's Personality Traits Dimension & Female & 152 & $2.37 \pm 1.27$ & 1.593 & .112 \\
& Male & 153 & $2.15 \pm 1.07$ & & \\
\hline
\end{tabular}

In Table 3, while there was a significant difference $(\mathrm{p}<0.05)$ in the moral disengagement scale by gender, no significant difference was observed $(\mathrm{p}>0.05)$ in the athlete's perception regarding the coach's unethical behaviors scale.

Table 4. T-test analysis results of moral disengagement and athlete's perception regarding the unethical behaviors scales by National Team Participation Status

\begin{tabular}{llllll}
\hline & National Team Participation Status & $\mathrm{n}$ & Mean. Std.Dev. & $\mathrm{t}$ & $\mathrm{p}$ \\
\hline Moral Disengagement & Participated in National Team & 98 & $2.83 \pm .987$ & -2.361 & .019 \\
& Have not participated in National Team & 207 & $3.11 \pm .979$ & & \\
Coach-Athlete Relationship & Participated in National Team & 98 & $2.46 \pm 1.10$ & .208 & .835 \\
& Have not participated in National Team & 207 & $2.43 \pm .984$ & & \\
Coach's Sportsmanship & Participated in National Team & 98 & $1.71 \pm .775$ & .401 & .689 \\
Dimension & Have not participated in National Team & 207 & $1.67 \pm .712$ & & \\
Coach's Personality Traits & Participated in National Team & 98 & $2.34 \pm 1.26$ & .776 & .439 \\
Dimension & Have not participated in National Team & 207 & $2.22 \pm 1.14$ & & \\
\hline
\end{tabular}

In Table 4 , while there was a significant difference $(p<0.05)$ in the moral disengagement scale by national team participation status, no significant difference was observed $(p>0.05)$ in the athlete's perception regarding the coach's unethical behaviors scale.

Table 5. T-test analysis results of moral disengagement and athlete's perception regarding the coaches' unethical behaviors scales by Punishment Status

\begin{tabular}{llllll}
\hline & Punishment Status & $\mathrm{n}$ & Mean. Std.Dev. & $\mathrm{t}$ & $\mathrm{p}$ \\
\hline Moral Disengagement & Punished & 69 & $3.24 \pm 1.018$ & -2.135 & .034 \\
& Not punished & 236 & $2.96 \pm .973$ & & \\
Coach-Athlete Relationship & Punished & 69 & $2.50 \pm 1.02$ & .547 & .585 \\
& Not punished & 236 & $2.42 \pm 1.02$ & & \\
Coach's Sportsmanship Dimension & Punished & 69 & $1.79 \pm .746$ & 1.347 & .179 \\
& Not punished & 236 & $1.65 \pm .727$ & & .609 \\
Coach's Personality Traits Dimension & Punished & 69 & $2.32 \pm 1.13$ & .512 & .609 \\
& Not punished & 236 & $2.24 \pm 1.19$ & & \\
\hline
\end{tabular}

In Table 5, while there was a significant difference $(\mathrm{p}<0.05)$ in the moral disengagement scale by punishment status, no significant difference was observed $(p>0.05)$ in the athlete's perception regarding the coach's unethical behaviors scale. 
Table 6. Anova analysis results of moral disengagement and athlete's perception regarding the coaches' unethical behaviors scales by Branch

\begin{tabular}{lllllll}
\hline & Branch & $\mathrm{n}$ & Mean. \pm Std.Dev. & $\mathrm{F}$ & $\mathrm{p}$ & Tukey \\
\hline Moral disengagement & Basketball & 88 & $2.93 \pm .922$ & 5.328 & .005 & Football/Volleyball \\
& Football & 96 & $3.29 \pm 1.076$ & & & Football/Basketball \\
& Volleyball & 121 & $2.88 \pm .926$ & & & \\
Coach-Athlete Relationship & Basketball & 88 & $2.18 \pm .953$ & 4.737 & .009 & Football/Basketball \\
& Football & 96 & $2.63 \pm 1.024$ & & & \\
Coach's Sportsmanship & Volleyball & 121 & $2.49 \pm 1.037$ & & & \multirow{2}{*}{ Football/Volleyball } \\
Dimension & Basketball & 88 & $1.61 \pm .636$ & 4.697 & .010 & Football/Basketball \\
Coach's Personality Traits & Football & 96 & $1.87 \pm .761$ & & & \\
Dimension & Volleyball & 121 & $1.59 \pm .752$ & & & \\
& Basketball & 88 & $2.09 \pm 1.11$ & 2.212 & .111 & \\
& Football & 96 & $2.45 \pm 1.22$ & & & \\
\hline
\end{tabular}

In Table 6, significant difference $(\mathrm{p}<0.05)$ was observed in the moral disengagement scale and in the "coach-athlete relationship" and "coach's sportsmanship dimension" of the athlete's perception regarding the coach's unethical behaviors scale.

Table 7. T-test analysis results of moral disengagement and athlete's perception regarding the coaches' unethical behaviors scales by level of meeting with their coaches

\begin{tabular}{llllll}
\hline & $\begin{array}{l}\text { Level of Meeting with } \\
\text { Their Coaches }\end{array}$ & $\mathrm{n}$ & Mean Std. Dev. & $\mathrm{t}$ & $\mathrm{p}$ \\
\hline Moral disengagement & Sufficient & 184 & $2.98 \pm .988$ & .872 & .384 \\
& Insufficient & 121 & $3.08 \pm .990$ & & \\
Coach-Athlete Relationship & Sufficient & 184 & $2.21 \pm .962$ & -5.003 & .000 \\
& Insufficient & 121 & $2.79 \pm 1.016$ & & \\
Coach's Sportsmanship Dimension & Sufficient & 184 & $1.55 \pm .668$ & -4.051 & .000 \\
& Insufficient & 121 & $1.89 \pm .779$ & & \\
Coach's Personality Traits Dimension & Sufficient & 184 & $1.99 \pm 1.024$ & -5.118 & .000 \\
& Insufficient & 121 & $2.67 \pm 1.284$ & & \\
\hline
\end{tabular}

In Table 7 , while there was significant difference $(p<0.05)$ in all sub-dimensions of athlete's perception regarding the unethical behaviors scale by the level of athletes' meeting with their coaches, no significant difference was observed $(p>0.05)$ in moral disengagement scale.

Table 8. T-test analysis results of moral disengagement and athlete's perception regarding the coaches' unethical behaviors scales by the variable of Does meeting with coach in social environment contribute to team unity

\begin{tabular}{lllllll}
\hline & $\begin{array}{l}\text { Contribution to } \\
\text { Team Unity }\end{array}$ & $\mathrm{n}$ & Mean \pm Std.Dev. & $\mathrm{t}$ & $\mathrm{p}$ \\
\hline Moral disengagement & Yes & 237 & $3.02 \pm .981$ & -.069 & .945 \\
& No & 68 & $3.03 \pm 1.02$ & & \\
Coach-Athlete Relationship Dimension & Yes & 237 & $2.28 \pm .951$ & -5.422 & .000 \\
& No & 68 & $3.01 \pm 1.064$ & & & .028 \\
Coach's Sportsmanship Dimension & Yes & 237 & $1.64 \pm .676$ & -2.210 & \\
& No & 68 & $1.86 \pm .885$ & & .000 \\
Coach's Personality Traits Dimension & Yes & 237 & $2.10 \pm 1.098$ & -4.466 & \\
& No & 68 & $2.81 \pm 1.298$ & & & \\
\hline
\end{tabular}

In Table 8, while there was significant difference $(p<0.05)$ in all sub-dimensions of athlete's perception regarding the unethical behaviors scale for the question of Does meeting with coach in social environments contribute to team unity, no significant difference was observed $(\mathrm{p}>0.05)$ in moral disengagement scale. 
Table 9. Anova analysis results of moral disengagement and athlete's perception regarding the coaches' unethical behaviors scales by the level of communication with their coaches

\begin{tabular}{lllllll}
\hline & $\begin{array}{l}\text { Communication } \\
\text { Level }\end{array}$ & $\mathrm{n}$ & Mean \pm Std. Dev. & $\mathrm{F}$ & $\mathrm{p}$ & Tukey \\
\hline Moral disengagement & Good & 201 & $3.01 \pm 1.01$ & .432 & .650 & - \\
& Medium & 85 & $3.00 \pm .890$ & & & \\
& Bad & 19 & $3.23 \pm 1.11$ & & & $\mathrm{Bad} / \mathrm{Medium}$ \\
Coach-Athlete Relationship & Good & 201 & $2.11 \pm .927$ & 59.849 & .000 & $\mathrm{Bad} / \mathrm{Good}$ \\
& Medium & 85 & $2.84 \pm .750$ & & & $\mathrm{Bad} / \mathrm{Medium}$ \\
& Bad & 19 & $4.15 \pm .674$ & & & $\mathrm{Bad} / \mathrm{Good}$ \\
Coach's Sportsmanship & Good & 201 & $1.60 \pm .689$ & 8.857 & .000 & $\mathrm{Bad} / \mathrm{Medium}$ \\
Dimension & Medium & 85 & $1.74 \pm .726$ & & & $\mathrm{Bad} / \mathrm{Good}$ \\
Coach's Personality Traits & Bad & 19 & $2.31 \pm .900$ & & & .000 \\
Dimension & Good & 201 & $1.87 \pm .982$ & 59.932 & & \\
& Medium & 85 & $2.77 \pm 1.069$ & & & \\
\hline
\end{tabular}

In Table 9, while there was significant difference $(\mathrm{p}<0.05)$ in all sub-dimensions of athlete's perception regarding the unethical behaviors scale by communication level with their coaches, no significant difference was observed $(\mathrm{p}>0.05)$ in moral disengagement scale.

Table 10. Correlation analysis results of scales

\begin{tabular}{lllll}
\hline & & \multicolumn{2}{l}{ Athlete's perception regarding the coaches' unethical behaviors scale } \\
\cline { 2 - 4 } & & $\begin{array}{l}\text { Coach-Athlete Relationship } \\
\text { Dimension }\end{array}$ & Coach's Sportsmanship & $\begin{array}{l}\text { Coach's Personality Traits } \\
\text { Dimensions }\end{array}$ \\
\hline Moral Disengagement & $\mathrm{P}$ & $.117^{*}$ & $.187^{* *}$ & $.113^{*}$ \\
& $\mathrm{R}$ & .042 & .001 & .048 \\
& $\mathrm{n}$ & 305 & 305 & 305 \\
\hline
\end{tabular}

According to the correlation analysis carried out, Table 10 shows that it was determined that there is a positive low-level significant correlation between moral disengagement and all sub-dimensions of athlete's perception regarding coach's unethical behaviors scale.

\section{Discussion}

In this study, the correlation between moral disengagement level of team athletes and unethical behaviors they perceived from their coaches depending on unethical behaviors they perceived from their coaches was determined. According to the findings of study, while it was determined that there are significant differences in all sub-dimensions of Athlete's Perception Regarding the Coaches' Unethical Behaviors Scale by Age, no significant difference was observed in Moral Disengagement Scale. It was determined that the athletes aged between 16-18 have lower unethical behavior average scores perceived from their coaches than both the athletes aged between 19-21 and over 23. This may be due to the fact that they are at the beginning of professional life as of age and the expectations of the coaches can be focused on more experienced athletes. According to the findings of Altın and Özsarı (2017)'s studies, it was stated that improvement is seen in moral decision-making behavior based on maturation with increasing age. In the study carried out by Özbek and Nalbant (2016) on moral decision-making behaviors of young athletes in Turkish Republic of Northern Cyprus, no statistical difference was reported in the moral decision-making behavior sub-dimensions due to age variable. In Gürpınar and Kurşun (2013)'s study, the differences in scale total scores and the sub-dimension called respect for the opponent, management and rules by age were assessed as significant. According to this, sportsmanship scores of athletes aged 22 and over are higher than the athletes aged 21 or under. In the study in which Gürpınar (2014) examined the moral decision-making behaviors of athletes studying in middle and high school in terms of sports variables, it was observed that moral decision-making behaviors are higher in inexperienced athletic students than the experienced athletes are.

While significant difference was determined in Moral Disengagement Scale by Gender, no significant difference was seen in Athlete's Perception Regarding the Coaches' Unethical Scale by Gender. According to this, men have higher level of moral disengagement than women have. In other words, it can be said that female athletes adopt the athletic moral and ethical behaviors much more in comparison with male athletes. Unlike our study, 
Güven and Öncü (2012) stated that the athletes' perception regarding their coaches' unethical behaviors didn't change by gender. When the similar studies to ours are examined, Gürpınar (2014) and Weiss and Bredemeier (1990) have stated that the moral decision-making behaviors of athletes differ by gender, and male athletes exhibit more unsportsmanlike behaviors than female athletes do. Dolaşır-Tuncel and Büyüköztürk (2009) determined that the obedience level of female athletes regarding the ethical principles included in coaches' responsibilities was higher than male athletes' obedience level. In Topan's (2011) study, the behaviors related to the sub-dimensions of Multi-dimensional Sports Orientation Scale were examined, and it was determined that female students were more advanced than male students in terms of compliance with social norms and respecting rules and management. Güllü (2018) concluded that women have much more respect for their opponents and are more in line with social norms. In the study carried out by Akoğlu, Ayyıldız and Sunay (2019), while no statistically significant difference was determined between the athletes' sportsmanship behaviors and moral disengagement level in sports, the moral disengagement level of male athletes was found higher in comparison to female athletes.

Significant difference was determined in Moral Disengagement Scale by National Team Participation Status. According to this, the athletes who haven't participated in national team have higher moral disengagement level than the athletes participated in national team. It can be shown as the main reason of this detection that while the athletes struggle to prove themselves in order to be elected for national team, they may exhibit more ambitious and furious behaviors, and become distanced from athletic moral rules and principles. In our study, no significant difference was obtained in the Athlete's Perception Regarding the Coaches' Unethical Behaviors Scale by National Team Participation Status. Unlike our study, Güven and Öncü (2012) found out that the athletes who couldn't participate in national team have higher perception level regarding their coaches' unethical behaviors than the athletes participated in national teams.

While significant difference was seen in Moral Disengagement Scale by Punishment Status, no significant difference was observed in Athlete's Perception Regarding the Coaches' Unethical Behaviors Scale by Punishment Status. At that rate, the athletes who have been punished have higher moral disengagement level than the athletes who haven't been punished. It has been observed that the athletes who have been punished previously cannot forget the process they have taken and continue to act against their opponents against sportive merit and moral rules instead of taking lessons from this situation.

Considering the Moral Disengagement and Athlete's Perception Regarding the Coaches' Unethical Behaviors Scales by Branch, significant differences were determined in the sub-dimensions which are "Coach-Athlete Relationship" and "Coach's Sportsmanship Dimension". According to this, the moral disengagement level of football players in addition to coach-athlete relationship and coach's perception of unethical behavior in sportsmanship dimension were higher than basketball and volleyball players were. It can be concluded that the specific characteristics and competitive level of football and other branches can be quite determinant in exhibiting or not exhibiting the ethical attitudes and behaviors. According to Gürpınar and Kurşun (2013)'s study, it was concluded that basketball players are more respectful than the football players are. In the study carried out by Gürpınar (2014), it was found that the scores of the moral decision-making behavior of the students who were interested in contact sports were higher than the students who were interested in non-contact sports. Tsai and Fung (2005) put forward in their study that the football players pay less attention to the sportsmanship in comparison to the volleyball players. According to Sofia and Cruz (2017), athletes with higher levels of physical contact and athletes from lower or younger categories of competition tended to be more aggressive than the athletes who were interested in sports with lower levels of contact and higher competitive levels. Balcikanlı and Yildiran (2018) indicated that empathy skills and prosocial behaviors were quite low in team sports with close physical contact while the most researched field has been the football. Türksoy Işım, Güvendi and Toros (2019) determined the fact in their study conducted on football players that those who have the climate of performance were much likely to become distant from moral principles in the field.

While significant differences were determined in all sub-dimensions of Athlete's Perception Regarding the Coaches' Unethical Behaviors Scale by Level of Meeting with Their Coaches, no significant difference was observed in Moral Disengagement Scale by Level of Meeting with Their Coaches. Unethical behavior perception of those who assume their level of meeting with their coaches isn't adequate is higher than the ones who assume it enough. Considering the survey item seeking for the answer for the question whether meeting with coach in social environment contributes to the team unity, significant differences were determined in all sub-dimensions of Athlete's Perception Regarding the Coaches' Unethical Behaviors Scale by the Variable of Whether Meeting with Coach in Social Environment Contribute to the Team Unity but no significant difference was observed in Moral Disengagement Scale by the Variable of Whether Meeting with Coach in Social Environment Contribute 
to the Team Unity. The coach's unethical behavior perception level of those who think that meeting with the coach in social environment contributes to the team unity is lower than those who think it will not work. While significant differences were determined in all sub-dimensions of Athlete's Perception Regarding the Coaches' Unethical Behaviors Scale by Level of Communication with Their Coaches, no significant difference was observed in Moral Disengagement Scale by Level of Communication with Their Coaches. According to this, the unethical behavior perception level of those who evaluate their communication with their coaches as poor is higher than the athletes who think their communication with their coaches is moderate or good. Under these circumstances, having good level of communication with athletes' coaches and meeting with them in social environments other than trainings and competitions affect the athletes' thought against their coaches positively. Besides, they become capable of understanding their coaches' behaviors and the underlying reasons. On the contrary, those who have poor communication level with their coaches and don't meet with them in social environments don't know their own coaches very well. As Altıntaş, Çetinkalp and Aşçı (2012) also indicated, the coach-athlete relationship that includes communication processes and reciprocal positive manners enables the appropriate environment to be established in which the athletes' motivation and satisfaction increase and they are able to improve their skills.

It was determined in our study that there is low-level positive significant correlation in all sub-dimensions of Moral Disengagement and Athlete's Perception Regarding the Coaches' Unethical Behaviors Scale. According to the correlation analysis, when the unethical behavior of athletes perceived by their coaches increases, their level of moral disengagement also increases similarly. At that rate, we can say that coaches' behaviors are vital determinant of unethical behaviors exhibited by athletes.

In conclusion, the unethical behavior level perceived by athletes from their coaches and the level of moral disengagement increase simultaneously. It was determined that the unethical behavior perception level of athletes who think that their level of meeting with coaches is inadequate, this kind of meetings doesn't contribute to the team unity, and have poor communication level with their coaches perceive the unethical behaviors of coaches much more than the others do. When the results are analyzed, it can be said that much positive contribution can be obtained in athletes' perception against their coaches by supporting the coach-athlete relationship with social environment. However, considering the football players' moral disengagement and perception level regarding the coaches' unethical behaviors which is higher in comparison with the basketball and volleyball players, it can be explained by the obvious popularity difference existing in favor of football, and intense competitive environment in addition to pressure of winning. In other words, since football is anymore a sector in which incredible amount of money is invested and processed throughout the world, it is potential to witness violence in both field and tribunes. Therefore, this pressure may lead both coaches and athletes to unethical behaviors and moral disengagement. The coaches, who should be exemplary for their athletes in relation to the moral terms, can show unethical behaviors in the name of winning because of the pressure of management or their personality traits or ambitions, and they can affect their athletes in this direction. In this respect, the frequency of unethical behaviors exhibited by coaches might be reduced if the coaches are regularly taken into the seminars in compliance with the professional ethics principles. Unless they comply with the rules, they must know that they will be exposed to various sanctions. By this means, the moral disengagement tendency of athletes may be prevented.

\section{References}

Akoğlu, H. E., Ayyıldız, E., \& Sunay, H. (2019, 21-24 Mart). Uluslararası spor organizasyonlarına katılan sporcuların sporda ahlaktan uzaklaşma ve sportmenlik davranışlarının incelenmesi. 2. Dünya Spor Bilimleri Araştırmaları Kongresi, Manisa/Türkiye.

Altın, M., \& Özsarı, A. (2017). Sporcu eğitim merkezlerinde yatılı olarak eğitim gören sporcuların ahlaki karar alma tutumları. International Journal of Cultural and Social Studies, 3(1), 133-145.

Altıntaş, A., Çetinkalp, Z., \& Aşçı, H. (2012). Antrenör-sporcu ilişkisinin değerlendirilmesi: geçerlik ve güvenirlik çalışması. Hacettepe Spor Bilimleri Dergisi, 23(3), 119-128.

Avc1, K. S., Çepikkurt, F., \& Kale, E. K. (2018). Examination of the relationship between coach-athlete communication levels and perceived motivational climate for volleyball players. Universal Journal of Educational Research, 6(2), 346-353. https://doi.org/10.13189/ujer.2018.060218

Balçıkanlı, S. G., \& Yıldıran, I. (2018). Elit salon hokeyi oyuncularında empatik beceri ile prososyal davranışlar arasındaki ilişki. Gazi Beden Eğitimi ve Spor Bilimleri Dergisi, 23(1), 1-8.

Başer, E. (1998). Uygulamalı spor psikolojisi. Ankara: Bağırgan Yayımevi. 
Boardley, I. D., \& Kavussanu, M. (2008). The moral disengagement in sport scale-short. Journal of Sports Sciences, 26(14), 1507-1517. https://doi.org/10.1080/02640410802315054

Büyüköztürk, Ş. (2012). Sosyal bilimler için veri analizi el kitabı. Ankara: Pegem A Yayıncılık.

Charles, A. (1999). Bucher, Deborah Wuest; Foundations of physical education exercise and sport (p. 22). Newyork: McGraw-Hill Companies.

Dolaşır-Tuncel, S., \& Büyüköztürk, Ş. (2009). Antrenörlerin mesleki etik ilkeleri nelerdir? Nasıl ölçülür? Ölçek geliştirme: Ölçeğin Geçerlik ve güvenirliği. Spormetre Beden Eğitimi ve Spor Bilimleri Dergisi, 7(4), 159-168. https://doi.org/10.1501/Sporm_0000000166

Eitzen, S. D. (2006). Fairandfoul. USA: Rowman \& Little field Publishers, Inc.

Elik, T. (2017). Güneydoğu Anadolu bölgesi futbol takımlarında amatör olarak futbol oynayan sporculartn sportmenlik yönelimleri ve empatik eğilim düzeyleri. Yüksek Lisans Tezi, İstanbul Gelişim Üniversitesi Sağlık Bilimleri Enstitüsü, İstanbul.

Güllü, S. (2018). Sporcuların antrenör-sporcu ilişkisi ile sportmenlik yönelimleri üzerine bir araştırma. Spormetre, 16(4), 190-204.

Gürpınar, B. (2014). Sporcu ortaokul ve lise öğrencilerinin spora ait değişkenler açısından ahlaki karar alma tutumları. Eğitim ve Bilim, 39(176), 413-424.

Gürpınar, B. (2015). Sporda ahlaktan uzaklaşma ölçeği kısa formunun türk kültürüne uyarlanması: geçerlik ve güvenirlik çalışması. Ankara Üniversitesi Spor Bilimleri Fakültesi, 13(1), 57-64. https://doi.org/10.1501/Sporm_0000000269

Gürpınar, B., \& Kurşun, S. (2013). Basketbolcuların ve futbolcuların sportmenlik yönelimleri. Mediterranean Journal of Humanities, 3(1), 171-176. https://doi.org/10.13114/MJH/20131660

Güven, Ö., \& Öncü, E. (2012). Antrenörlerin etik dışı davranışları ile ilgili sporcu algısı ölçeğinin geliştirilmesi. Spormetre Beden Eğitimi ve Spor Bilimleri Dergisi, 5(2), 67-75. https://doi.org/10.1501/Sporm_0000000222

İnanç, Y. B., Bilgin, M., \& Atıcı, K. M. (2004). Gelişsim psikolojisi çocuk ve ergen gelişimi. Adana: Nobel Kitabevi.

Karakoç, Ö., Yüksek, S., Aydın, A. D., Karakoç, B., Yetiş, Ü., \& Baydil, B. (2011). Milli takım düzeyindeki erkek judocuların kulüp antrenörlerinde gözlemledikleri etik dışı davranışlar. Kastamonu Eğitim Dergisi, 19(1), 321-332.

Keskin, A., Özdemir, A., Tunç, A., \& Devrilmez, E. (2018). Lise spor takımlarında antrenör sporcu ilişkisinin incelenmesi. Sportive (Spor, Eğitim ve Rekreasyon Dergisi), 1(1), 1-11.

Özbek, O., \& Nalbant, U. (2016, 01-04 Kasım). Kuzey Kıbrıs Türk Cumhuriyeti'ndeki genç sporcuların ahlaki karar alma tutumlart (p. 14). Uluslararası Spor Bilimleri Kongresi, Antalya.

Sofia, R., \& Cruz, J. F. A. (2017). Unveiling anger and aggression in sports: The effects of type of sport, competitive category and success level. Journal of Sport Psychology, 26(2), 21-28.

Tanrıverdi, H. (2012). Sports ethics and violence. The Journal of Academic Social Science Studies, 5(8), 1071-1093. https://doi.org/10.9761/jasss_361

Tiryaki, Ş. (2000). Spor psikolojisi-kavramlar, kuramlar ve uygulama. Anakara: Tekağaç Eylül Kitap ve Yayınevi.

Topan, A. (2011). Ortä̈ğretim kurumlarında okullar arası futbol müsabakalarına katılan öğrencilerin falrplay anlayışlarının kulüp deneyimlerine göre incelenmesi. Yüksek Lisans Tezi, Gazi Üniversitesi Eğitim Bilimleri Enstitüsü, Ankara.

Topkaya, İ. (2007). Hareket beden eğitimi spor üzerinde ögrenme ve öğretimin temelleri. Ankara: Nobel Yayın Dağıtım.

Tsai, E., \& Fung, L. (2005). Sportspersonship in youth basketball and volleyball players. Athletic insight. The Online Journal of Sport Psychology, 7(2), 37-46.

Türksoy-Işım, A., Güvendi, B., \& Toros, T. (2019). Amatör lig futbolcularında sporda ahlaktan uzaklaşma, güdüsel iklim ve karar verme. International Journal of Social Sciences and Education Research, 5(1), 54-62. https://doi.org/10.24289/ijsser.483295 
Weiss, M. R., \& Bredemeier, B. J. L. (1990). Moral development in sport. Exercise and Sport Sciences Reviews, 18(1), 331-378. https://doi.org/10.1249/00003677-199001000-00015

\section{Copyrights}

Copyright for this article is retained by the author, with first publication rights granted to the journal.

This is an open-access article distributed under the terms and conditions of the Creative Commons Attribution license (http://creativecommons.org/licenses/by/4.0/). 